\title{
Genetic relationships of lactose and freezing point with minerals and coagulation traits predicted from milk mid-infrared spectra in Holstein cows
}

\author{
A. Costa, ${ }^{1}$ G. Visentin ${ }^{2 *}$ M. De Marchi, ${ }^{1}$ M. Cassandro, ${ }^{1}$ and M. Penasa ${ }^{1}$ \\ ${ }^{1}$ Department of Agronomy, Food, Natural Resources, Animals and Environment, University of Padova, Viale dell'Università 16, \\ 35020 Legnaro (PD), Italy \\ ${ }^{2}$ Associazione Nazionale Allevatori della razza Frisona e Jersey Italiana (ANAFIJ), Via Bergamo 292, 26100 Cremona, Italy
}

\begin{abstract}
The aim of the present study was to assess the relationships of lactose percentage (LP), lactose yield (LY), and freezing point (FRP) with minerals and coagulation properties predicted from mid-infrared spectra in bovine milk. To achieve this purpose, we analyzed 54,263 test-day records of 4,297 Holstein cows to compute (co) variance components with a linear repeatability animal model. Parity, stage of lactation, season of calving, and herd-test-date were included as fixed effects in the model, and additive genetic animal, within- and acrosslactation permanent environment, and residual were included as random effects. Lactose percentage was more heritable $(0.405 \pm 0.027)$ than $\mathrm{LY}(0.121 \pm 0.021)$ and FRP $(0.132 \pm 0.014)$. Heritabilities $( \pm$ standard error $)$ of predicted milk minerals varied from $0.375 \pm 0.027$ for $\mathrm{Na}$ to $0.531 \pm 0.028$ for $\mathrm{P}$, and those of milk coagulation properties ranged from $0.348 \pm 0.052$ for rennet coagulation time to $0.430 \pm 0.026$ for curd firming time. Lactose percentage showed favorable (negative) genetic correlations with milk somatic cell score (SCS) and FRP, and it was almost uncorrelated with caseinrelated minerals $(\mathrm{Ca}$ and $\mathrm{P}$ ) and coagulation properties. Moreover, LP was strongly correlated with $\mathrm{Na}(-0.783$ \pm 0.022 ), a mineral known to increase in the presence of intramammary infection (IMI) and high somatic cell count. Indeed, $\mathrm{Na}$ is the main osmotic replacer of lactose in mastitic milk when the blood-milk barrier is altered during IMI. Being strongly associated with milk yield, LY did not favorably correlate with coagulation properties, likely because of the negative correlation of this trait with protein and casein percentages. Milk FRP presented moderate and null genetic associations with $\mathrm{Na}$ and SCS, respectively. Results of the present study suggest that the moderate heritability of LP and
\end{abstract}

Received July 13, 2018.

Accepted April 4, 2019.

*Corresponding author: giuliovisentin@anafi.it its genetic correlations with IMI-related traits ( $\mathrm{Na}$ and SCS) could be exploited for genetic selection against mastitis. Moreover, selection for LP would not impair milk coagulation characteristics or $\mathrm{Ca}$ and $\mathrm{P}$ content, which are important for cheesemaking.

Key words: lactose, milk mineral, cheesemaking, genetic correlation, somatic cell count

\section{INTRODUCTION}

Milk lactose has gained interest in the scientific community in recent years and some studies have investigated genetic and nongenetic sources of variation for this trait (Sneddon et al., 2015; Haile-Mariam and Pryce, 2017; Costa et al., 2019b). Lactose is the major milk osmotic compound and thus the main compound responsible for milk volume (Fox et al., 2015); this means that it would not be biologically possible to strongly reduce lactose percentage (LP) through, for example, genetic selection and feeding strategies, to meet requirements of people intolerant to lactose. In contrast to fat and protein concentrations, LP is not affected by milk dilution through DIM, and its lactation curve mirrors that of milk yield (MY) and lactose yield (LY), with a peak in early lactation (Haile-Mariam and Pryce, 2017). When IMI occurs, the inflammatory response factors of white cells are responsible for damaging the epithelium surrounding alveoli. This alters the mammary blood barrier equilibrium, causing a decrease of LP in the alveoli, which is osmotically balanced by some blood minerals (mainly $\mathrm{Na}$ and $\mathrm{Cl}$ ). This mechanism explains why mastitic milk has greater electrical conductivity, lower LP, and a saltier taste than milk of healthy cows (Norberg et al., 2006; Brandt et al., 2010; Fox et al., 2015). Supporting this, an inverse relationship exists between LP and SCS, the latter being the most common indicator of IMI and mastitis in dairy cows (Damm et al., 2017; Shook et al., 2017). For example, Miglior et al. (2007) estimated a genetic correlation of -0.20 between LP and SCS in 
Canadian Holsteins and Gillon et al. (2010) reported a higher negative value $(-0.38)$ in a multi-breed study in Belgium. By adopting a random regression model, Haile Mariam and Pryce (2017) observed an increase in the magnitude of the genetic correlation between these 2 traits in late lactation of multiparous cows. Indeed, they estimated a genetic correlation close to -0.50 in third-lactation cows at 300 DIM. The strongest phenotypic $(-0.66)$ and genetic $(-0.44)$ associations between LP and SCS were assessed by Vilas Boas et al. (2017) in Brazilian Gyr cows and by Stoop et al. (2007) in first-calving Holsteins, respectively. Miglior et al. (2007) and Haile-Mariam and Pryce (2017) estimated negative correlations ( -0.16 and -0.15 , respectively) between LP EBV and SCS EBV, highlighting that bulls with low EBV for LP are more likely to produce offspring with higher SCS; that is, more susceptible to mastitis. In addition, Costa et al. (2019a) estimated a negative genetic correlation $(-0.175)$ between LP and mastitis in Austrian Fleckvieh cattle. These findings, coupled with moderate to high heritability of LP (e.g., Stoop et al., 2007; Tiezzi et al., 2013; Costa et al., 2019a,b), make this trait an interesting indicator for the genetic improvement of cow udder health.

The variation of milk composition following an IMI, especially in terms of LP and mineral content, is thought to affect milk freezing point $\left(\mathbf{F R P},{ }^{\circ} \mathrm{C}\right)$. Milk FRP is closely dependent on water-soluble compounds and it is often used as an alert to the fraudulent addition of water to milk; indeed, milk with FRP values greater than $-0.520^{\circ} \mathrm{C}$ (i.e., values moving toward zero) are considered unsuitable for human consumption (European Union, 1992; Council Directive 92/46/EEC). From a genetic point of view, information on genetic parameters for FRP at the population level is scarce (Costa et al., 2019b).

The potential use of LP and FRP for selection purposes in the Italian production system depends on the magnitude and direction of genetic relationships with traits of economic relevance for the dairy industry, such as milk minerals and milk coagulation properties (MCP). Indeed, $82.2 \%$ of Italian bovine milk $(11,950,245 \mathrm{t}$ in 2017) is destined for cheese manufacture (CLAL, 2017, 2018; ISTAT, 2017); thus, milk minerals (especially $\mathrm{Ca}$ and $\mathrm{P}$ ) and $\mathrm{MCP}$ play a key role in the efficiency of milk transformation. In Italy, MCP have economic relevance and are included in the payment systems of Parmigiano Reggiano (Summer et al., 2015) and Trentingrana (Penasa et al., 2016b) cheeses to reward or penalize farmers for milk coagulation ability. Routine determination of mineral contents and MCP through reference laboratory methods in individual milk samples is expensive, and the use of mid-infrared spectroscopy to predict these traits from available mid-infrared spectra is a cheaper and faster approach to collect information at the population level (Soyeurt et al., 2009; Visentin et al., 2016). Therefore, the aim of the present study was to quantify phenotypic and genetic correlations of milk LP, LY, and FRP with SCS, predicted minerals, and predicted MCP in Holstein cows.

\section{MATERIALS AND METHODS}

\section{Data and Editing}

A data set of 143,965 test-day records of 11,230 Holstein cows in 676 herds of Bolzano province (northern Italy) was available for statistical investigation. Milk samples were collected from January 2011 to December 2014 during the routine recording scheme and analyzed in the laboratory of the South Tyrolean Dairy Association (Südtiroler Sennereiverband, Bolzano, Italy) for $\mathrm{LP}$, fat percentage $(\mathbf{F P})$, protein percentage $(\mathbf{P P}), \mathrm{CN}$ percentage, and FRP using a Milkoscan FT6000 (Foss Electric A/S, Hillerød, Denmark). Somatic cell count (cells $/ \mu \mathrm{L}$ ) was determined using Fossomatic FC (Foss Electric A/S) and converted to SCS to achieve normal distribution by applying the formula of Wiggans and Shook (1987): SCS $=\log _{2}(\mathrm{SCC} / 100)+3$. Rennet coagulation time (RCT, min), curd firmness $30 \mathrm{~min}$ after rennet addition $\left(\mathbf{a}_{\mathbf{3 0}}, \mathrm{mm}\right)$, curd firming time $\left(\mathbf{k}_{\mathbf{2 0}}\right.$, min), and $\mathrm{Ca}, \mathrm{P}, \mathrm{Mg}, \mathrm{Na}$, and $\mathrm{K}$ were predicted from the same data set using stored spectra information and the mid-infrared prediction models developed and validated by Visentin et al. (2016). Coefficients of determination in external validation of prediction models for $\mathrm{Ca}, \mathrm{P}, \mathrm{Mg}, \mathrm{K}$, and $\mathrm{Na}$ were $0.67,0.68,0.65,0.69$, and 0.40 , respectively, and for $\mathrm{RCT}, \mathrm{k}_{20}$, and $\mathrm{a}_{30}$ they were $0.54,0.56$, and 0.52 , respectively (Visentin et al., 2016).

Cows were retained in the data set if they had known sire and dam, were in parity 1 to 6 , and were between 6 and 480 DIM. The range of age at calving within each parity was 20 to 40,32 to 58,44 to 76,56 to 94,68 to 112 , and 75 to 120 mo for first-, second-, third-, fourth-, fifth-, and sixth-parity animals, respectively. Moreover, values of MY, composition, FRP, minerals, and MCP deviating more than 3 standard deviations from the respective means were treated as missing, whereas records characterized by SCC $<1,000$ or $>15,000,000$ cells were discarded. Lactose yield was calculated by multiplying LP and MY. Finally, at least 3 records per cow within lactation and at least 3 observations per contemporary group (herd-test-date, HTD) were guaranteed. The average number of records per cow within lactation in the final data set was 7 and ranged from 3 to 17 . 


\section{Genetic Parameters}

To limit computational memory and time, genetic parameters of the studied traits were estimated on a randomly selected subset of $40 \%$ of herds $(n=269)$, which resulted in 54,263 records from 4,297 cows, daughters of 784 sires and 3,484 dams. Means and variation of the traits were very similar in the 2 sets. Also, the frequency of observations across parities of the subset (31.24, $27.91,18.78,12.23,6.49$, and $3.35 \%$ for first, second, third, fourth, fifth, and sixth parity, respectively) mirrored those of the whole data set $(31.19,27.90,18.88$, $11.88,6.67$, and $3.48 \%$ ). Six generations of ancestors were traced back, leading to a pedigree file of 16,925 individuals. Variance and covariance components were estimated in ASReml 4.1 (Gilmour et al., 2015) using single-trait and bivariate repeatability animal models, respectively. The general form of the model, in matrix notation, was as follows:

$$
\mathbf{y}=\mathbf{X} \mathbf{b}+\mathbf{Z}_{\mathrm{p}} \mathbf{p}+\mathbf{Z}_{\mathrm{w}} \mathbf{w}+\mathbf{Z}_{\mathrm{a}} \mathbf{a}+\mathbf{e},
$$

where $\mathbf{y}$ is the vector of phenotypic records for MY, LY, LP, CN, PP, FP, FRP, SCS, Ca, P, Mg, K, Na, RCT, $\mathrm{a}_{30}$, and $\mathrm{k}_{20}$; $\mathbf{b}$ is the vector of fixed effects of contemporary group (HTD: 6,622 levels), parity order (1 to 6 ), season of calving (4 classes: December to February, March to May, June to August, and September to November), and stage of lactation [13 classes of $30 \mathrm{~d}$ each, except for the first class (6 to 30 DIM), the second to last class (330 to 390 DIM), and the last class (391 to $480 \mathrm{DIM})]$; $\mathbf{p}$ is the vector of solutions for random permanent environmental effect across lactation; w is the vector of solutions for random permanent environmental effect within lactation; $\mathbf{a}$ is the vector of solutions for random additive genetic effect of the animal; $\mathbf{e}$ is the vector of random residuals; and $\mathbf{X}, \mathbf{Z}_{\mathrm{p}}, \mathbf{Z}_{\mathrm{w}}$, and $\mathbf{Z}_{\mathrm{a}}$ are incidence matrices relating the corresponding effects to the dependent variable. Random effects were assumed to be normally distributed with null means and variance-covariance structures of additive genetic, permanent environmental across-lactation, permanent environmental within-lactation, and residual effects in the bivariate analyses that were equal to $\mathbf{G} \otimes \mathbf{A}, \mathbf{P} \otimes$ $\mathbf{I}, \mathbf{W} \otimes \mathbf{I}$, and $\mathbf{R} \otimes \mathbf{I}$, respectively, where $\mathbf{G}$ is the $2 \times$ 2 additive genetic (co) variance matrix, $\mathbf{P}$ is the $2 \times 2$ (co)variance matrix of permanent environmental effects across lactation, $\mathbf{W}$ is the $2 \times 2$ (co)variance matrix of permanent environmental effects within lactation, $\mathbf{R}$ is the residual (co)variance matrix, $\mathbf{A}$ is the additive genetic relationship matrix among individuals, $\mathbf{I}$ is an identity matrix of appropriate order, and $\otimes$ denotes the Kronecker product. The phenotypic variance was the sum of additive genetic, permanent environmental across-lactation, permanent environmental withinlactation, and residual variances. Heritability was computed as the ratio of the additive genetic variance to the phenotypic variance, and repeatability was the ratio of the sum of additive genetic and permanent environmental variances to the phenotypic variance. Genetic (or phenotypic) correlations (r) were calculated as

$$
\mathrm{r}=\frac{\operatorname{cov}_{1,2}}{\sqrt{\sigma_{1}^{2} \times \sigma_{2}^{2}}},
$$

where $\operatorname{cov}_{1,2}$ is the additive genetic (or phenotypic) covariance between traits 1 and 2 , and $\sigma_{1}^{2}$ and $\sigma_{2}^{2}$ are the additive genetic (or phenotypic) variances of trait 1 and trait 2 , respectively.

\section{RESULTS AND DISCUSSION}

\section{Descriptive Statistics}

Lactose percentage ranged from 4.06 to $5.46 \%$ and averaged $4.76 \%$ across all 6 parities (Table 1). The average LP was equal to the value reported by Scarso et al. (2017) in a multi-breed study in Ireland and slightly lower than the mean LP reported by Sneddon et al. (2015) in a data set including Holstein, Jersey, and other minor breeds reared in New Zealand, and by Haile-Mariam and Pryce (2017) for Australian Holstein and Jersey cows. The mean LP of the present study was lower than the average value $(4.90 \%)$ reported by Penasa et al. (2016a) for the same breed in Italy; however, this difference was expected because the study of Penasa et al. (2016a) included only primiparous cows, whose milk has greater LP than milk of multiparous cows (Haile-Mariam and Pryce, 2017). This was also the case in the present study; indeed, primiparous cows produced milk with greater LP $(4.82 \%)$ than did later parity cows $(4.76 \%$ for secondparity to $4.71 \%$ for sixth-parity cows). Lactose yield averaged $1.31 \mathrm{~kg} / \mathrm{d}$ and varied from 0.17 to $2.61 \mathrm{~kg} / \mathrm{d}$ (Table 1). Tiezzi et al. (2013) reported a greater mean value $(1.55 \mathrm{~kg} / \mathrm{d})$ using data of Italian Holsteins, and Sneddon et al. (2015) calculated a lower value $(0.71$ $\mathrm{kg} / \mathrm{d})$ in New Zealand. Milk FRP averaged $-0.525^{\circ} \mathrm{C}$ with a coefficient of variation $(\mathbf{C V})$ of $1.90 \%$ (Table 1 ), and it averaged $-0.527,-0.525$, and $-0.524^{\circ} \mathrm{C}$ in first, second, and third parity, respectively, and -0.523 in later parities. Hanuš et al. (2010) reported lower mean $\left(-0.532^{\circ} \mathrm{C}\right)$ and $\mathrm{CV}(0.90 \%)$ for FRP in a multi-breed study. Overall, means of predicted milk minerals (Table 1) were in agreement with those reported by Buitenhuis 
Table 1. Summary statistics of milk traits

\begin{tabular}{|c|c|c|c|c|c|}
\hline Trait & $\mathrm{n}$ & Mean & Minimum & Maximum & $\mathrm{CV}, \%$ \\
\hline \multicolumn{6}{|l|}{ Yield, $\mathrm{kg} / \mathrm{d}$} \\
\hline Milk & 143,343 & 27.45 & 3.70 & 51.00 & 27.87 \\
\hline Lactose & 143,343 & 1.31 & 0.17 & 2.61 & 28.57 \\
\hline \multicolumn{6}{|l|}{ Composition, \% } \\
\hline Lactose & 143,965 & 4.76 & 4.06 & 5.46 & 3.36 \\
\hline Casein & 143,588 & 2.66 & 1.84 & 3.53 & 10.53 \\
\hline Protein & 143,569 & 3.38 & 2.22 & 4.53 & 11.24 \\
\hline Fat & 143,567 & 4.02 & 2.10 & 5.94 & 15.67 \\
\hline Freezing point, ${ }^{\circ} \mathrm{C}$ & 143,965 & -0.525 & -0.552 & -0.498 & 1.90 \\
\hline SCS & 143,965 & 2.92 & -3.64 & 10.22 & 60.27 \\
\hline \multicolumn{6}{|l|}{ Mineral content, $\mathrm{mg} / \mathrm{kg}$} \\
\hline Calcium & 143,098 & $1,317.00$ & 823.10 & $1,821.15$ & 12.03 \\
\hline Phosphorus & 143,435 & 928.76 & 600.68 & $1,258.75$ & 11.48 \\
\hline Magnesium & 125,078 & 138.47 & 62.29 & 193.87 & 19.14 \\
\hline Potassium & 143,003 & $1,505.24$ & $1,102.00$ & $1,909.11$ & 8.54 \\
\hline Sodium & 143,642 & 427.05 & 273.52 & 581.59 & 11.75 \\
\hline \multicolumn{6}{|l|}{ Milk coagulation properties } \\
\hline Rennet coagulation time, min & 135,130 & 23.25 & 4.67 & 32.25 & 16.00 \\
\hline Curd firming time, min & 143,854 & 6.07 & 0.30 & 10.00 & 20.43 \\
\hline Curd firmness, $\mathrm{mm}$ & 121,092 & 16.14 & 0.003 & 65.25 & 57.31 \\
\hline
\end{tabular}

et al. (2015) for milk minerals measured using the reference method in Danish Holsteins and by Visentin et al. (2018) for infrared-predicted milk minerals in dairy and dual-purpose cattle breeds. The CV of milk minerals were comparable to those of $\mathrm{FP}, \mathrm{PP}$, and $\mathrm{CN}$, and they ranged from $8.54 \%(\mathrm{~K})$ to $19.14 \%(\mathrm{Mg})$. Means for $\mathrm{RCT}, \mathrm{k}_{20}$, and $\mathrm{a}_{30}$ were $23.25 \mathrm{~min}, 6.14 \mathrm{~min}$, and 16.07 $\mathrm{mm}$, respectively, with $\mathrm{a}_{30}$ exhibiting much greater $\mathrm{CV}$ $(57.31 \%)$ than RCT $(16.00 \%)$ and $\mathrm{k}_{20}(20.43 \%)$, in agreement with Cassandro et al. (2015).

\section{Additive Genetic Variation, Heritability, and Repeatability}

Genetic parameters for milk minerals and MCP in the present study were estimated using predictions from models that were moderately accurate, and estimates have to be interpreted with caution, especially with regard to $\mathrm{Na}$, which was the least predictable trait. Nevertheless, mid-infrared predictions could be used as indicator traits at the population level to drive breeding strategies. For example, Cecchinato et al. (2009) reported coefficients of determination from 0.61 to 0.69 for RCT models, and from 0.46 to 0.52 for $\mathrm{a}_{30}$ models, which were similar to accuracies of prediction models for RCT and $\mathrm{a}_{30}$ of Visentin et al. (2016). Despite the moderate phenotypic correlations between measured and predicted MCP, their genetic counterparts were stronger (Cecchinato et al., 2009), supporting the role of mid-infrared predictions as indicator traits in breeding programs aiming to improve milk coagulation ability. It is likely that genetic correlations between measured and predicted milk minerals are also greater than their phenotypic counterparts, but unfortunately we could not estimate such genetic relationships in the current study because the reference data set was small for this purpose.

The coefficient of additive genetic variation $\left(\mathbf{C V}_{\mathbf{a}}\right)$ of LP was lower (1.95\%) than that of other milk traits, except FRP $(0.40 \%$; Table 2$)$, and was very close to that (1.89\%) reported by Visentin et al. (2017) for the same trait in a multi-breed study. This finding was expected because lactose has a physiological osmotic function at the mammary cell level and its content in milk does not exhibit wide variation. The $\mathrm{CV}_{\mathrm{a}}$ of $\mathrm{LY}(6.35 \%)$ was close to that of MY (6.18\%), and for minerals it ranged from $3.98 \%$ for $\mathrm{K}$ to $6.71 \%$ for $\mathrm{P}$. The greatest $\mathrm{CV}_{\mathrm{a}}$ was obtained for $\mathrm{a}_{30}(28.65 \%)$ and SCS (19.80\%; Table 2).

Lactose percentage was more heritable $(0.405)$ than LY (0.121). Similarly, Scarso et al. (2017) and Visentin et al. (2017) estimated heritabilities for LP that were in agreement with those obtained in the present study. The heritability of LP was similar to that of FP, PP, and $\mathrm{CN}$ but much greater than that assessed for $\mathrm{MY}$ and SCS. Milk FRP was lowly heritable (0.132) and repeatable $(0.267)$, indicating that its variation depends mainly on temporary environmental rather than on genetic and permanent environmental factors (Costa et al., 2019b). Among milk minerals, the least and most heritable were $\mathrm{Na}(0.375)$ and $\mathrm{P}(0.531)$, respectively, with $\mathrm{Ca}, \mathrm{Mg}$, and $\mathrm{K}$ exhibiting intermediate heritability of approximately 0.45 (Table 2). These estimates were slightly lower than those assessed by van Hulzen et al. (2009) for $\mathrm{Ca}$ (0.57), P (0.62), and $\mathrm{Mg}$ (0.60) using the reference method in 1,948 milk samples of Dutch Friesian cows, and in agreement with estimates of Soy- 
eurt et al. (2012) for infrared-predicted Ca (0.50), P (0.55), and $\mathrm{Mg}$ (0.52) in milk of first-calving Holsteins. Repeatabilities of milk minerals were moderately high, between $0.558(\mathrm{Ca})$ and $0.686(\mathrm{P})$, highlighting that they were less affected by temporary environmental effects than by other traits. Estimates of heritability and repeatability for MCP ranged from 0.348 (RCT) to $0.430\left(\mathrm{k}_{20}\right)$ and from $0.564\left(\mathrm{a}_{30}\right)$ to $0.591\left(\mathrm{k}_{20}\right)$, respectively (Table 2). Standard errors of heritability and repeatability estimates ranged from 0.014 to 0.052 and 0.006 to 0.012 , respectively (Table 2 ).

The proportion of phenotypic variance explained by permanent environmental effects was heterogeneous among traits, and it ranged from $11.2 \%$ (Ca) to $46.6 \%$ (MY). In particular, this proportion was much larger for LY (45.5\%) than for LP (20.2\%), and it was small for milk minerals, with values between $11.2 \%$ (Ca) and $23.3 \%(\mathrm{Na})$; the latter results could be due to the nature of milk minerals, which are physiologically determined and less affected by permanent environmental effects. Similar to milk minerals, FRP was marginally influenced by temporary and permanent environmental effects.

\section{Correlations}

Standard errors of genetic $\left(\mathbf{r}_{\mathrm{a}}\right)$ and phenotypic $\left(\mathbf{r}_{\mathbf{p}}\right)$ correlations estimated in the present study ranged from 0.009 to 0.117 and from 0.000 to 0.013 , respectively (Table 3). The negative and strong $\mathrm{r}_{\mathrm{a}}$ between LP and
$\mathrm{Na}(-0.783$; Table 3$)$ emphasized the link between LP and this mastitis-associated mineral (Fox et al., 2015). Indeed, $\mathrm{Na}$ has been found to be positively related to milk SCC (Ogola et al., 2007; Soyeurt et al., 2008; Haron et al., 2014). The $\mathrm{r}_{\mathrm{a}}$ between LP and $\mathrm{K}$ was negative $(-0.432)$, similar to results of Visentin et al. (2018), who estimated $\mathrm{r}_{\mathrm{a}}$ from -0.62 to -0.46 between LP and $\mathrm{K}$ using random regression models. The $\mathrm{r}_{\mathrm{a}}$ between LP and $\mathrm{Mg}$ content was moderately weak $(-0.275)$ and was almost null between LP and $\mathrm{Ca}$, and between LP and $\mathrm{P}$ content. Except for the weak correlation with $\mathrm{k}_{20}(-0.118)$, LP was not genetically associated with MCP, suggesting that potential selection for LP would not impair milk coagulation ability. Using multivariate factor analysis, Macciotta et al. (2012) identified a factor named "udder health" (high LP and low SCC) and estimated its heritability (0.137) and $r_{a}$ with MY (0.132), composition (0.126), acidity (0.168), and coagulation ability (0.008). The $\mathrm{r}_{\mathrm{a}}$ between LP and SCS was -0.172 (Table 3). Despite the weak correlation, this finding suggested that genetic selection for increased LP would result, on average, in a reduction of SCS. Gillon et al. (2010) reported $\mathrm{r}_{\mathrm{a}}$ of -0.35 between LP and SCS in a multi-breed study, and Miglior et al. (2007) and Visentin et al. (2017) estimated values of -0.20 and -0.28 in Canadian Holsteins and Irish mixed-breed herds, respectively. A stronger $r_{a}(-0.44)$ was reported by Stoop et al. (2007) for Holstein cows in the Netherlands. Overall, the magnitude and direction of $r_{p}$ resembled those of $r_{a}$ (Table 3). In particular, LP was

Table 2. Coefficient of genetic variation $\left(\mathrm{CV}_{\mathrm{a}}\right)$, heritability $\left(\mathrm{h}^{2}\right)$, repeatability $(\mathrm{t})$, and proportion of phenotypic variance explained by the 2 permanent environmental effects $\left(c^{2}\right)$ for milk yield and composition traits, freezing point, SCS, mineral contents, and coagulation properties

\begin{tabular}{lrrccc}
\hline Trait & $\mathrm{n}$ & $\mathrm{CV}_{\mathrm{a}}, \%$ & $\mathrm{~h}^{2}(\mathrm{SE})$ & $\mathrm{t}(\mathrm{SE})$ & $\mathrm{c}^{2}$ \\
\hline $\begin{array}{l}\text { Yield, kg/d } \\
\quad \text { Milk }\end{array}$ & 54,041 & 6.18 & $0.119(0.021)$ & $0.585(0.006)$ & 0.466 \\
$\quad$ Lactose & 54,041 & 6.35 & $0.121(0.021)$ & $0.576(0.006)$ & 0.455 \\
$\quad$ Composition, \% & & & & & \\
$\quad$ Lactose & 54,263 & 1.95 & $0.405(0.027)$ & $0.607(0.007)$ & 0.202 \\
$\quad$ Casein & 54,086 & 5.16 & $0.430(0.027)$ & $0.642(0.007)$ & 0.212 \\
$\quad$ Protein & 54,089 & 5.30 & $0.423(0.027)$ & $0.625(0.007)$ & 0.202 \\
$\quad$ Fat & 54,113 & 8.02 & $0.345(0.025)$ & $0.511(0.008)$ & 0.166 \\
Freezing point, ${ }^{\circ} \mathrm{C}$ & 54,263 & 0.40 & $0.132(0.014)$ & $0.267(0.007)$ & 0.135 \\
SCS & 54,263 & 19.80 & $0.131(0.019)$ & $0.516(0.006)$ & 0.385 \\
$\quad$ Mineral content, mg/kg & & & & & \\
$\quad$ Calcium & 53,919 & 5.59 & $0.446(0.024)$ & $0.558(0.008)$ & 0.112 \\
$\quad$ Phosphorus & 54,075 & 6.71 & $0.531(0.028)$ & $0.686(0.007)$ & 0.155 \\
$\quad$ Magnesium & 47,171 & 5.13 & $0.470(0.027)$ & $0.602(0.008)$ & 0.132 \\
$\quad$ Potassium & 53,877 & 3.98 & $0.450(0.025)$ & $0.582(0.008)$ & 0.132 \\
$\quad$ Sodium & 54,150 & 5.92 & $0.375(0.027)$ & $0.608(0.007)$ & 0.233 \\
$\quad$ Milk coagulation properties & & & & & \\
$\quad$ Rennet coagulation time, min & 50,984 & 7.57 & $0.348(0.052)$ & $0.589(0.012)$ & 0.241 \\
$\quad$ Curd firming time, min & 54,218 & 10.25 & $0.430(0.026)$ & $0.591(0.007)$ & 0.161 \\
$\quad$ Curd firmness, mm & 46,032 & 28.65 & $0.385(0.026)$ & $0.564(0.008)$ & 0.179 \\
\hline
\end{tabular}




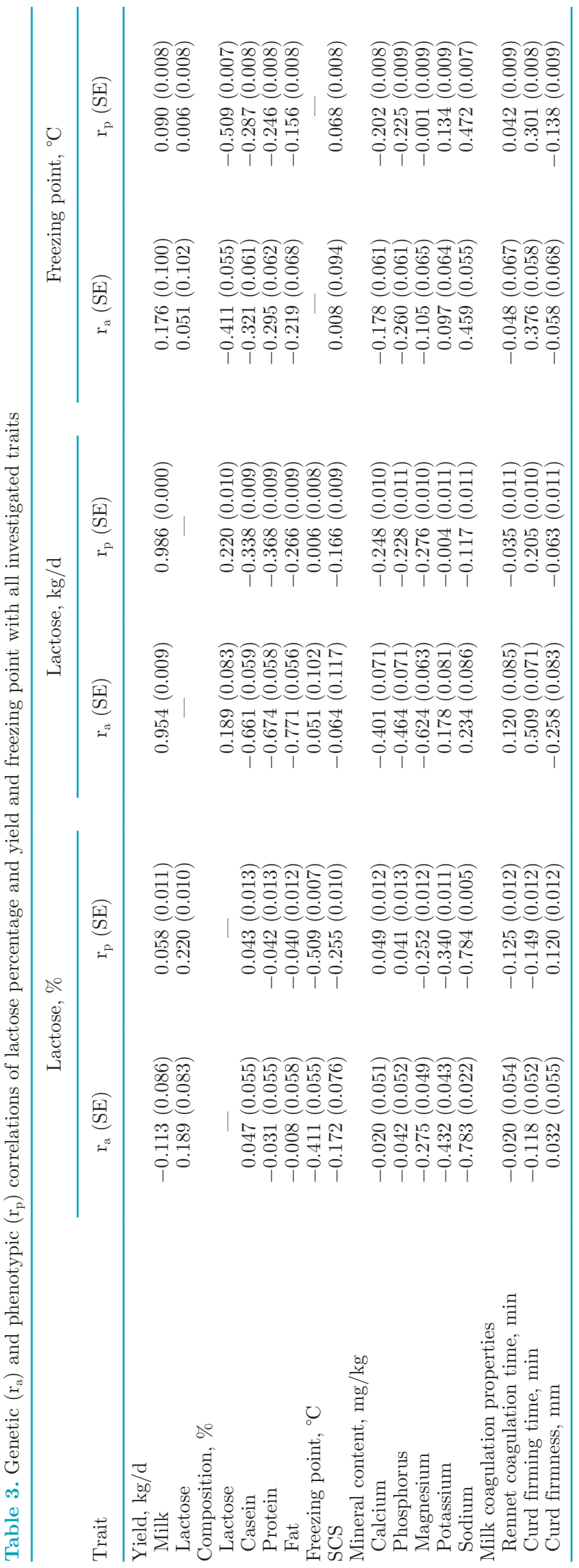

negatively correlated with $\mathrm{Mg}(-0.252)$, K (-0.340), and $\mathrm{Na}(-0.784)$. Lactose percentage was negatively phenotypically associated with SCS $(-0.255)$ and FRP $(-0.509)$, and it was weakly but favorably phenotypically related to $\mathrm{RCT}(-0.125), \mathrm{k}_{20}(-0.149)$, and $\mathrm{a}_{30}$ (0.120). Bezman et al. (2015) and Bland et al. (2015) reported favorable and moderate $r_{p}$ of LP with RCT and $\mathrm{a}_{30}$. These findings pointed out the positive role of milk lactose in the fermentation activities of lactic acid bacteria before and during cheesemaking.

Lactose percentage was weakly associated with MY and composition, in accordance with Sneddon et al. (2015), who estimated $\mathrm{r}_{\mathrm{a}}$ between -0.14 (LP with PP) and -0.05 (LP with FP), and Visentin et al. (2017), who reported $\mathrm{r}_{\mathrm{a}}$ between -0.22 (LP with PP) and 0.07 (LP with MY). By adopting random regression models, Haile-Mariam and Pryce (2017) estimated $r_{a}$ of LP with $\mathrm{PP}$ and FP that were positive at the beginning of the lactation, with estimates between 0.30 and 0.35 (LP with $\mathrm{PP}$ ) and 0.15 to 0.20 (LP with FP), and negative at the end of the lactation with estimates from -0.25 to -0.10 (LP with PP) and -0.20 to -0.05 (LP with FP). These findings may explain the overall average weak correlations between LP and milk composition when estimated using a repeatability animal model.

The $\mathrm{r}_{\mathrm{a}}$ between LP and LY was weakly positive (0.189; Table 3), which was somewhat expected because LP is osmotically determined during water uptake and LY is the product of LP and MY. The amount of synthesized lactose determines the volume of milk in mammary tissue; thus, a strong $\mathrm{r}_{\mathrm{a}}$ (0.954) was assessed between LY and MY, in accordance with the literature (Sneddon et al., 2015; Haile-Mariam and Pryce, 2017). Moreover, the strong negative $r_{\mathrm{a}}$ of LY with FP $(-0.771)$, PP $(-0.674)$, and CN $(-0.661)$ underlined that cows producing a high amount of lactose (i.e., high MY) were those producing a more diluted milk. Lactose yield was unfavorably genetically associated with RCT (0.120), $\mathrm{k}_{20}(0.509)$, and $\mathrm{a}_{30}(-0.258)$, and this could be due to the aforementioned strong negative genetic relationship between LY and P or CN. Also, unfavorable genetic correlations were assessed between LY and casein-related minerals, with estimates from -0.624 ( $\mathrm{LY}$ and $\mathrm{Mg}$ ) to -0.401 (LY and Ca; Table 3), confirming that genetic selection for higher LY (i.e., higher MY) could be detrimental for milk technological traits. Indeed, milk from high-producing cows is usually characterized by lower concentrations of constituents and poorer coagulation properties (Cassandro et al., 2008). Positive weak $r_{a}$ were assessed between LY and $\mathrm{Na}(0.234)$ and between LY and K (0.178). This finding indicated that cows yielding more lactose (and thus more milk) genetically tend to present higher milk Na content, which could be due to the greater susceptibility to mastitis and IMI 
that characterizes high-producing cows (Oltenacu and Broom, 2010). However, LY correlated weakly with SCS (-0.064). Overall, $r_{p}$ between LY and other traits investigated in the present study were lower than and of the same direction as their genetic counterparts, with very few exceptions (Table 3 ). In particular, $r_{p}$ between LY and minerals ranged from -0.276 ( $\mathrm{LY}$ and $\mathrm{Mg}$ ) to -0.004 ( $\mathrm{LY}$ and $\mathrm{Na}$ ), and they were even lower between LY and MCP.

Milk FRP depends mainly on the concentration of the different constituents in milk (Fox et al., 2015). Indeed, in the current study, FRP was favorably genetically associated with composition traits $(-0.411$ with LP to -0.219 with FP) and contents of $\mathrm{Ca}(-0.178), \mathrm{P}$ $(-0.260)$, and $\mathrm{Mg}(-0.105$; Table 3$)$. These estimates were very similar to those obtained for the $r_{p}$ and in agreement with previous reports (Harris and Bachman, 2003; Fox et al., 2015). Freezing point was moderately genetically related to $\mathrm{Na}(0.459)$ and $\mathrm{k}_{20}(0.376)$ and almost uncorrelated with $\mathrm{K}$ content, RCT, and $\mathrm{a}_{30}$. Both $r_{a}$ and $r_{p}$ between FRP and Na suggested that milk with a higher content of $\mathrm{Na}$ (a potential indicator of IMI) usually presents undesired (i.e., greater) values of FRP. Following this reasoning, we would expect a positive correlation between FRP and SCS; however, this was not the case, because the 2 traits did not correlate in the present study. Somatic cell score and clinical mastitis are not always strongly correlated $\left(\mathrm{r}_{\mathrm{a}}\right.$ from 0.62 to 0.74; Egger-Danner et al., 2015) and test-day SCS is an alert for subclinical and chronic cases, rather than of (sub-)acute inflammations because peaks could be missed during the gap (3 to $4 \mathrm{wk}$ ) between consecutive test days (Koeck et al., 2010). Moreover, according to the pathogen involved, the increase in SCS differs in terms of pattern, persistency, and rapidity (Heringstad et al., 2000; de Haas, 2003). Finally, it is worthwhile noting that the osmotic equilibrium of milk tends to be guaranteed in the presence of mastitis or high SCS, the decrease in LP being replaced by mineral constituents (Fox et al., 2015). Therefore, further research is needed to investigate genetic (co)variance components of milk FRP across DIM.

To assess the consistency of genetic and phenotypic correlations of the most innovative traits (i.e., milk mineral contents and MCP) across different subsets, 2 additional samples, each comprising $40 \%$ of herds, were randomly selected from the original data and compared with estimates of the subset discussed in the present study (Supplemental Table S1; https://doi.org/ 10.3168/jds.2018-15378). Results highlighted trivial differences between the same phenotypic correlations estimated in the 3 subsets. In terms of genetic relationships, the differences were greater, especially for asso- ciations that involved LY; nevertheless, the magnitude of standard errors suggested that estimates were not significantly different across the 3 subsets.

\section{CONCLUSIONS}

Genetically, LP of bovine milk was favorably associated with FRP and almost uncorrelated with caseinrelated minerals and coagulation properties. Both phenotypic and genetic correlations of LP with common milk indicators of mastitis (SCS and, in particular, Na) exist and thus LP could be exploited as an additional indicator of udder health for indirect selection against mastitis. Supported by results of the present study, selecting for higher LP would not impair milk coagulation ability at the population level, whereas selection for FRP would negatively affect $\mathrm{k}_{20}$. Milk minerals with nutritional and technological value $(\mathrm{Ca}, \mathrm{P}$, and $\mathrm{Mg}$ ) would not be affected by selection for higher LP and lower FRP. Finally, we found no evidence to indicate that an indirect undesired response in traditional milk quality traits (e.g., fat, protein, and casein percentages) would result in case of selection for LP.

\section{ACKNOWLEDGMENTS}

This study was supported by the University of Padova (Ricerca Scientifica fondi DOR-2017, project DOR1721792/17, Italy). The authors thank the South Tyrolean Dairy Association (Südtiroler Sennereiverband Bolzano, Italy) for performing milk analyses and providing data, and Anna Benedet (University of Padova, Italy) for support during data analysis. All authors contributed to the discussion of the results, commented on the manuscript, reviewed the paper, and approved the final version of the work.

\section{REFERENCES}

Bezman, D., L. Lemberskiy-Kuzin, G. Katz, U. Merin, and G. Leitner. 2015. Influence of intramammary infection of a single gland in dairy cows on the cow's milk quality. J. Dairy Res. 82:304-311. https://doi.org/10.1017/S002202991500031X.

Bland, J. H., A. S. Grandison, and C. C. Fagan. 2015. Evaluation of milk compositional variables on coagulation properties using partial least squares. J. Dairy Res. 82:8-14. https://doi.org/10.1017/ S0022029914000508.

Brandt, M., A. Haeussermann, and E. Hartung. 2010. Invited review: Technical solutions for analysis of milk constituents and abnormal milk. J. Dairy Sci. 93:427-436. https://doi.org/10.3168/jds.2009 -2565 .

Buitenhuis, B., N. A. Poulsen, L. B. Larsen, and J. Sehested. 2015. Estimation of genetic parameters and detection of quantitative trait loci for minerals in Danish Holstein and Danish Jersey milk. BMC Genet. 16:52. https://doi.org/10.1186/s12863-015-0209-9.

Cassandro, M., M. Battagin, M. Penasa, and M. De Marchi. 2015. Short communication: Genetic relationships of milk coagulation 
properties with body condition score and linear type traits in Holstein-Friesian cows. J. Dairy Sci. 98:685-691. https://doi.org/10 $.3168 / \mathrm{jds} .2014-8153$.

Cassandro, M., A. Comin, M. Ojala, R. Dal Zotto, M. De Marchi, L. Gallo, P. Carnier, and G. Bittante. 2008. Genetic parameters of milk coagulation properties and their relationships with milk yield and quality traits in Italian Holstein cows. J. Dairy Sci. 91:371376. https://doi.org/10.3168/jds.2007-0308.

Cecchinato, A., M. De Marchi, L. Gallo, G. Bittante, and P. Carnier 2009. Mid-infrared spectroscopy predictions as indicator traits in breeding programs for enhanced coagulation properties of milk. J. Dairy Sci. 92:5304-5313. https://doi.org/10.3168/jds.2009-2246.

CLAL. 2017. Italy: Milk production and utilization 2017. Accessed Nov. 23, 2018. https://www.clal.it/en/?section=bilancio_approv2 \&year $=2017$.

CLAL. 2018. Italy: Import/Export summary. Accessed Sep. 26, 2018. https://www.clal.it/en/index.php?section=riepilogo_istat.

Costa, A., C. Egger-Danner, G. Mészáros, C. Fuerst, M. Penasa, J. Sölkner, and B. Fuerst-Waltl. 2019a. Genetic associations of lactose and its ratios to other milk solids with health traits in Austrian Fleckvieh cows. J. Dairy Sci. 102:4238-4248. https://doi.org/ $10.3168 /$ jds.2018-15883.

Costa, A., N. Lopez-Villalobos, G. Visentin, M. De Marchi, M. Cassandro, and M. Penasa. 2019b. Heritability and repeatability of milk lactose and its relationships with traditional milk traits, somatic cell score and freezing point in Holstein cows. Animal 13:909-916. https://doi.org/10.1017/S1751731118002094.

European Union. 1992. Council Directive 92/46/EEC: Laying down the health rules for the production and placing on the market of raw milk, heat-treated milk and milk-based products.

Damm, M., C. Holm, M. Blaabjerg, M. N. Bro, and D. Schwarz. 2017. Differential somatic cell count-A novel method for routine mastitis screening in the frame of Dairy Herd Improvement testing programs. J. Dairy Sci. 100:4926-4940. https://doi.org/10.3168/ jds.2016-12409.

de Haas, Y. 2003. Somatic cell count patterns: Improvement of udder health by genetics and management. PhD Thesis. Wageningen Univ., Wageningen, the Netherlands.

Egger-Danner, C., J. B. Cole, J. E. Pryce, N. Gengler, B. Heringstad, A. Bradley, and K. F. Stock. 2015. Overview of new traits and phenotyping strategies in dairy cattle with a focus on functional traits. Animal 9:191-207. https://doi.org/10.1017/S1751731114002614.

Fox, P. F., T. Uniacke-Lowe, P. L. H. McSweeney, and J. A. O'Mahony. 2015. Dairy Chemistry and Biochemistry. Springer International Publishing, Basel, Switzerland.

Gillon, A., C. Bastin, H. Soyeurt, and N. Gengler. 2010. Genetic parameters of mastitis-correlated milk components in first parity dairy cows. Page 27 in Proc. 9th World Congress on Genetics Applied to Livestock Production, Leipzig, Germany. Accessed Jun. 10, 2018. https://orbi.uliege.be/handle/2268/69459.

Gilmour, A. R., B. J. Gogel, B. R. Cullis, S. J. Welham, and R. Thompson. 2015. ASReml User Guide. Release 4.1. VSN International Ltd., Hemel Hempstead, UK.

Haile-Mariam, M., and J. E. Pryce. 2017. Genetic parameters for lactose and its correlation with other milk production traits and fitness traits in pasture-based production systems. J. Dairy Sci. 100:3754-3766. https://doi.org/10.3168/jds.2016-11952 (Corrigendum. J. Dairy Sci. 100:6008-6008. https://doi.org/10.3168/jds .2017-100-7-6008).

Hanuš, O., J. Frelich, M. Tomáška, M. Vyletělová, V. Genčurová, J. Kučera, and J. Třináctý. 2010. The analysis of relationships between chemical composition, physical, technological and health indicators and freezing point in raw cow milk. Czech J. Anim. Sci. 55:11-29. https://doi.org/10.17221/1708-CJAS.

Haron, A. W., F. F. J. Abdullah, A. Tijjani, Y. Abba, L. Adamu, K. Mohammed, A. M. M. Amir, M. A. Sadiq, and M. A. M. Lila. 2014. The use of $\mathrm{Na}^{+}$and $\mathrm{K}^{+}$ion concentrations as potential diagnostic indicators of subclinical mastitis in dairy cows. Vet. World 7:966-969. https://doi.org/10.14202/vetworld.2014.966-969.

Harris, B., and K. C. Bachman. 2003. Nutritional and management factors affecting solids-not-fat, acidity and freezing point of milk.
University of Florida. Accessed Jan. 15, 2018. http://ufdcimages .uflib.ufl.edu/ir/00/00/47/70/00001/ds15600.pdf.

Heringstad, B., G. Klemetsdal, and J. Ruane. 2000. Selection for mastitis resistance in dairy cattle: A review with focus on the situation in the Nordic countries. Livest. Prod. Sci. 64:95-106. https://doi .org/10.1016/S0301-6226(99)00128-1.

ISTAT. 2017. Milk and dairy products. Accessed Nov. 23, 2018. http: //dati.istat.it/Index.aspx?lang=en\&SubSessionId=0bb31df9-67c9 -4d86-bf68-e49ddfaa1bc8.

Koeck, A., B. Heringstad, C. Egger-Danner, C. Fuerst, P. Winter, and B. Fuerst-Waltl. 2010. Genetic analysis of clinical mastitis and somatic cell count traits in Austrian Fleckvieh cows. J. Dairy Sci. 93:5987-5995. https://doi.org/10.3168/jds.2010-3451.

Macciotta, N. P. P., A. Cecchinato, M. Mele, and G. Bittante. 2012. Use of multivariate factor analysis to define new indicator variables for milk composition and coagulation properties in Brown Swiss cows. J. Dairy Sci. 95:7346-7354. https://doi.org/10.3168/ jds.2012-5546.

Miglior, F., A. Sewalem, J. Jamrozik, J. Bohmanova, D. M. Lefebvre, and R. K. Moore. 2007. Genetic analysis of milk urea nitrogen and lactose and their relationships with other production traits in Canadian Holstein cattle. J. Dairy Sci. 90:2468-2479. https://doi .org/10.3168/jds.2006-487.

Norberg, E., G. W. Rogers, J. Ødegård, J. B. Cooper, and P. Madsen. 2006. Genetic correlation between test-day electrical conductivity of milk and mastitis. J. Dairy Sci. 89:779-781. https://doi.org/10 .3168/jds.S0022-0302(06)72139-7.

Ogola, H., A. Shitandi, and J. Nanua. 2007. Effect of mastitis on raw milk compositional quality. J. Vet. Sci. 8:237-242. https://doi.org/ 10.4142/jvs.2007.8.3.237.

Oltenacu, P. A., and D. M. Broom. 2010. The impact of genetic selection for increased milk yield on the welfare of dairy cows. Anim. Welf. 19:39-49.

Penasa, M., M. De Marchi, and M. Cassandro. 2016a. Short communication: Effects of pregnancy on milk yield, composition traits and coagulation properties of Holstein cows. J. Dairy Sci. 99:48644869. https://doi.org/10.3168/jds.2015-10168.

Penasa, M., V. Toffanin, N. Cologna, M. Cassandro, and M. De Marchi. 2016b. Effects of dairy factory, milk casein content and titratable acidity on coagulation properties in Trentingrana dairy industry. J. Dairy Res. 83:242-248. https://doi.org/10.1017/ S0022029916000212.

Scarso, S., S. McParland, G. Visentin, D. P. Berry, A. McDermott, and M. De Marchi. 2017. Genetic and nongenetic factors associated with milk color in dairy cows. J. Dairy Sci. 100:7345-7361. https:/ /doi.org/10.3168/jds.2016-11683.

Shook, G. E., R. L. B. Kirk, F. L. Welcome, Y. H. Schukken, and P. L. Ruegg. 2017. Relationship between intramammary infection prevalence and somatic cell score in commercial dairy herds. J. Dairy Sci. 100:9691-9701. https://doi.org/10.3168/jds.2017-12810.

Sneddon, N. W., N. Lopez-Villalobos, S. R. Davis, R. E. Hickson, and L. Shalloo. 2015. Genetic parameters for milk components including lactose from test day records in the New Zealand dairy herd. N. Z. J. Agric. Res. 58:97-107. https://doi.org/10.1080/00288233 .2014 .978482

Soyeurt, H., V. Arnould, D. Bruwier, P. Dardenne, J.-M. Romnee, and N. Gengler. 2008. Relationship between lactoferrin, minerals, and somatic cells in bovine milk. J. Dairy Sci. 91(E-Suppl. 1):542-543. (Abstr.)

Soyeurt, H., D. Bruwier, J.-M. Romnee, N. Gengler, C. Bertozzi, D. Veselko, and P. Dardenne. 2009. Potential estimation of major mineral contents in cow milk using mid-infrared spectrometry. J. Dairy Sci. 92:2444-2454. https://doi.org/10.3168/jds.2008-1734.

Soyeurt, H., F. Dehareng, J.-M. Romnee, N. Gengler, and P. Dardenne. 2012. Genetics of the mineral contents in bovine milk predicted by mid-infrared spectrometry. Page 18 in Book of Abstracts of the 63rd Annu. Mtg. Eur. Fed. Anim. Sci., Bratislava, Slovakia. Wageningen Academic Publishers, Wageningen, the Netherlands.

Stoop, W. M., H. Bovenhuis, and J. A. M. van Arendonk. 2007. Genetic parameters for milk urea nitrogen in relation to milk produc- 
tion traits. J. Dairy Sci. 90:1981-1986. https://doi.org/10.3168/ jds.2006-434.

Summer, A., P. Franceschi, P. Formaggioni, and M. Malacarne. 2015. Influence of milk somatic cell content on Parmigiano-Reggiano cheese yield. J. Dairy Res. 82:222-227. https://doi.org/10.1017/ S0022029915000102.

Tiezzi, F., D. Pretto, M. De Marchi, M. Penasa, and M. Cassandro. 2013. Heritability and repeatability of milk coagulation properties predicted by mid-infrared spectroscopy during routine data recording, and their relationships with milk yield and quality traits. Animal 7:1592-1599. https://doi.org/10.1017/S1751731113001195.

van Hulzen, K. J. F., R. C. Sprong, R. van der Meer, and J. A. M. van Arendonk. 2009. Genetic and nongenetic variation in concentration of selenium, calcium, potassium, zinc, magnesium, and phosphorus in milk of Dutch Holstein-Friesian cows. J. Dairy Sci. 92:5754-5759. https://doi.org/10.3168/jds.2009-2406.

Vilas Boas, D. F., A. E. Vercesi Filho, M. A. Pereira, L. C. Roma Junior, and L. El Faro. 2017. Association between electrical conductivity and milk production traits in Dairy Gyr cows. J. Appl.
Anim. Res. 45:227-233. https://doi.org/10.1080/09712119.2016 .1150849 .

Visentin, G., S. McParland, M. De Marchi, A. McDermott, M. A. Fenelon, M. Penasa, and D. P. Berry. 2017. Processing characteristics of dairy cow milk are moderately heritable. J. Dairy Sci. 100:6343-6355. https://doi.org/10.3168/jds.2017-12642.

Visentin, G., M. Penasa, P. Gottardo, M. Cassandro, and M. De Marchi. 2016. Predictive ability of mid-infrared spectroscopy for major mineral composition and coagulation traits of bovine milk by using the uninformative variable selection algorithm. J. Dairy Sci. 99:8137-8145. https://doi.org/10.3168/jds.2016-11053.

Visentin, G., M. Penasa, G. Niero, M. Cassandro, and M. De Marchi. 2018. Phenotypic characterisation of major mineral composition predicted by mid-infrared spectroscopy in cow milk. Ital. J. Anim. Sci. 17:549-556. https://doi.org/10.1080/1828051X.2017.1398055.

Wiggans, G. R., and G. E. Shook. 1987. A lactation measure of somatic cell count. J. Dairy Sci. 70:2666-2672. https://doi.org/10 .3168/jds.S0022-0302(87)80337-5. 